\title{
IMPROVING THE EFFICIENCY OF THE VILNIUS CITY TRANSPORT SYSTEM \\ IN THE CONTEXT OF SUSTAINABLE MOBILITY AND MULTIMODALITY
}

\section{ALDONA JARAŠŪNIENĖ*, DOMAS ČESNULAITIS \\ Faculty of Transport Engineering, Vilnius Gediminas Technical University, Vilnius, Lithuania}

Received 31 August 2020; accepted 29 March 2021

\begin{abstract}
Vilnius is one of the most dynamic cities in Eastern Europe experiencing a continuous increase in the number of vehicles and the development of road transport networks associated with a wide range of environmental impacts, greenhouse gas emissions, depletion of raw materials, energy and fuel consumption and also a social impact, expressed in the quality of life of people, human health, traffic jam and economic impact because of generated losses of economic efficiency. Different strategies have been adopted by the city of Vilnius to tackle the increasing traffic flows with a modest impact and without a long-term effect. This article aims at analysing the measures taken to improve the transport system of Vilnius city and presenting different types of solution, which could improve interconnectivity of passenger transport as ways to solve the problems of the urban transport system.
\end{abstract}

Keywords: transport system, sustainable mobility, multimodality, "Park and Ride" platform, benefits.

\footnotetext{
* Corresponding author. E-mail: aldona.jarasuniene@vilniustech.lt

Aldona JARAŠŪNIENÉ (ORCID ID 0000-0002-9804-0064) 
THE BALTIC JOURNAL

OF ROAD

AND BRIDGE

ENGINEERING

$2021 / 16(3)$

\section{Introduction}

The urban transport system is a set of transport infrastructures and modes consisting of separate objects that fulfils the main functions of the transport industry, passenger and freight urban movements (Minalga, 2009).

The urban transport system is considered to be fully operational when the connection meets the need of all traffic participants and all vehicles (Baublys, Vasilis Vasiliauskas, 2011).

Qualitative fulfilment of this need requires proper flow planning and infrastructure in urban accesses. Improper interconnection of urban and suburban road networks often leads to congestion during peak hours. It is therefore necessary to develop the rural and suburban road network in a balanced way and to integrate it into the urban transport system (Vasilis Vasiliauskas, 2013).

It is very important to take into the account the transportation sector on the environment. In order to minimise environmental damage, a suitable infrastructure and hybrid electric vehicles are being developed, a sustainable mobility and other environmentally-friendly measures are being promoted (Jaržemskis et al., 2012).

The increase of the population and the number of vehicles and the acceleration of mobility, the urban transport system must constantly improve and respond to the needs created by the society (Sodiq et al., 2019).

The level of the transport system development is best showing by traffic efficiency. Efficient traffic means fast, high-quality, safe, convenient, financially profitable and low-polluting travelling through transport infrastructure (Jaržemskis, A., \& Jaržemskis, V., 2017). The main and most obvious reasons for reducing transport efficiency are congestion. This is a global problem, which is the result of controlled and uncontrolled reasons. The causes of road traffic congestion have been elucidated, but this does not always help find long-term solutions that will completely solve the problem (Rodrigue et al., 2006). Taking into account all the causes of traffic jams, four main categories of their appearance can be identified: environmental impact; mechanical problems; human fault and infrastructure imperfections (Zhuang et al., 2017).

Investing in sustainable urban design and turning each neighbourhood into a particular settlement centre would solve many problems related to the traffic congestion. The overall need for travel would be greatly reduced, as the main reasons for leaving the district would be to reach a workplace, to fulfil specific wishes and to visit events (Rokicki \& Stepniak, 2018). 
The sustainable design of a neighbourhood, bringing together all the of the Vilnius City Transport System most important objects nearby, can also have a positive impact on the development of a healthy lifestyle. All commodities are easily accessible on foot or by bicycle, changing the outdated habits of society when it comes to use car. A good localization of the commodities in the region and the development of a comprehensive approach would contribute to an improvement in the quality of life in the long term (Rokicki \& Stepniak, 2018).

Alternative and environmentally-friendly means of traveling are increasingly being considered. They are designed to make journey faster and more attractive than it is now by usual ways of traveling. Sustainable mobility plan (SMP) in the cities are used to achieve such goals.

It is very important to create the right conditions for each mode of transport to reveal its strengths. For this reason, bicycle networks are being set up in cities, bicycle parking and sharing sites; "Park and Ride" sites and terminals connecting different modes of transport are being built (Sodiq et al., 2019).

The SMP offers alternative travelling options to see that combining them with each other can offer a faster journey.

The biggest problem is the constantly increasing number of population and cars in the cities that exceed the capacity of road traffic than can be controlled; solving this problem by increasing capacities always leads to even greater hidden need. A strategically effective measure in fighting against the increasing demand for the road transport system is alternative modes of traveling that allow for sustainable and multimodal mobility, involving different modes of transport and measures that help distribute traffic flows.

\section{Research methodology}

An interview was conducted to substantiate or refute the information gathered during the analysis of the documents. The interview method is applied in sociology and social psychology to obtain oral information provided in the research program; this method is considered to be one of the most effective methods of qualitative research (Tidikis, 2003). The main reason for choosing the qualitative (expert evaluation) method is that expert evaluation allows obtaining objective results in order to achieve objectivity in the analysed problem (Tidikis, 2003). Interviews can be structured, semi-structured, and unstructured. In this work, a structured interview method was chosen - a questionnaire was prepared. The structured interview was chosen because of its main advantage - it ensured and allowed for the comparison of expert 
THE BALTIC JOURNAL

OF ROAD

AND BRIDGE

ENGINEERING

2021/16(3)

opinions with each other, so it was possible to perform a detailed analysis of the expert opinion, which allowed obtaining information improving the efficiency of the Vilnius city transport. Additional information was also sought from the personal experience of experts and direct contact with transport issues. Inventory management experts were interviewed during the interview. According to K. Kardelis (2016), the survey of purposefully selected people-specialists with knowledge in a certain field allows achieving scientific objectivity. The experts were selected on the basis of the principles of the expert assessment methodology. The expert is a person with a lot of knowledge and experience, and the opinion of the expert group does not differ much from the actual solution to the problem. The experts were also selected on the basis of their experience in the field of transport system, as well as the fact that they were directly confronted with the urban transport problems. The aim of the interviews was to evaluate different aspect of Vilnius "Park and Ride" sites, to analyse the opinion of experts on the platform advantages and disadvantages of the most important aspects of the site for potential users. After the analysis of documents, as well as the questionnaire survey, the experts were asked questions in order to assess the possibilities of solving the problems.

\section{Analysis of transport system in Vilnius city}

Observing the growth of the number of cars in Vilnius city, it is understandable that in the fight against traffic congestion it is necessary to take innovative and modern solutions aimed not only at solving the current problems, but also providing benefits in the long run. At this time, most European cities focus on the promotion of sustainable, mobile and environmentally-friendly way of traveling, while avoiding the use of motor vehicles and their generated traffic congestion. For the implementation of such goals, considering the proposals presented in the White Paper and other European Union transport policy regulations and directives, a Vilnius city SMP has been prepared. In order to achieve the goals of the SMP, three strategic orientations have been outlined, which aim at implementing this plan: formation of public traveling habits by promoting walking, cycling and public transport; management of motorized transport by eliminating transit traffic in Vilnius old Town and achieving a general decrease in the level of motorization; coordination of urban development by regulating urban dispersion and ensuring the efficiency of urban logistics (Vilniaus miesto darnaus judumo plano santrauka, n. d.). 
During the period of 2019-2020, the bicycle network in the city of the Vilnius City Transport System in the Context expanded by more than 40 kilometres. Over the next few years, the aim will be to complete the formation of a full-fledged network of bicycle routes, which will allow for convenient and safe access to all urbanized of Sustainable districts, even further away from the city centre. During the warm and Multimodality season, as many as 37 CycloCity bicycle rental points can be found in the city centre and its surroundings. Such items together with electric scooter rental stations are being set up next to the closest city centre "Park and Ride" sites, increasing the interaction between different transport options. The integration of a well-developed and user-friendly cycling network into the transport system is becoming an increasingly attractive alternative to fuel-powered transport, connecting important routes for residents and allowing fuel-free vehicles to travel without polluting nature.

According to the data provided by the municipality, investments in the development and improvement of cyclist and pedestrian path network in 2019 reached 7 million EUR (Pèsčiųjų takų plètra, n. d.).

In order to achieve a more efficient functioning of the transport system in Vilnius city, in addition to the improvement of public transport, the promotion of sustainable mobility and multimodal traveling in the city, a well-developed infrastructure network of streets and roads is vital. As a result, reduced traffic congestion has a diverse positive impact on the city. It is reflected in improved road traffic ability,

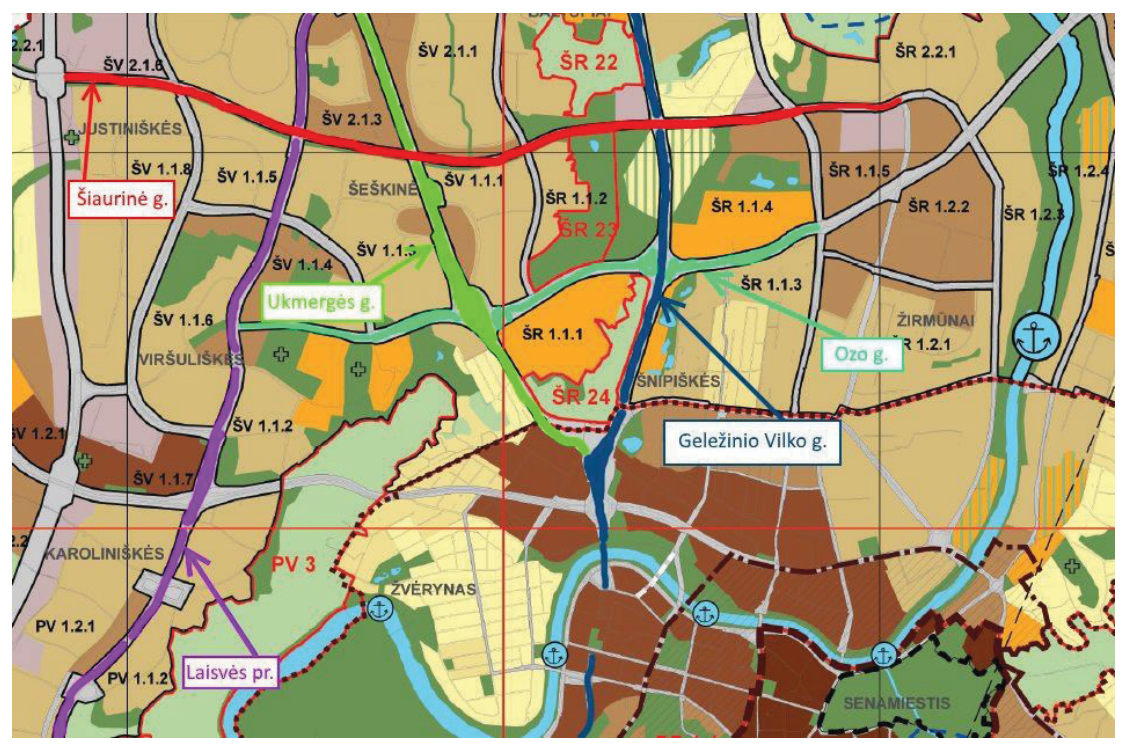

Figure 1. Siaurinè Street in Vilnius 
increased satisfaction of traffic participants, their safety on the road and reduced travel time, all of which contribute to increasing economic and environmental benefits. For this reason, the Vilnius road network and all the necessary infrastructure are constantly being expanded, improved and modernized.

A significant and positive boost in the fight against congestion is expected from the implementation of the Siaurine Street construction project presented in 2018 and scheduled to start in 2020 (Fig. 1) Šiaurinè gatvè (n. d.).

Vilnius city municipality sees the uninterrupted movement of traffic flows as another infrastructural measure to increase flow management. In addition to technical traffic improvement measures, the city is also improving its technological environment. In 2018, the automated traffic light regulation and control system was renewed ITS Vilniaus transporto sistemoje (n. d.).

Vilnius city municipality considers the uninterrupted movement of traffic flows as another infrastructural measure to increase traffic. Besides the technical measures to better manage traffic, the city is also improving its technological environment. Indeed, in 2018, the city renewed its traffic lights automated regulating and controlling system.

The number of inhabitants and the area of the city territory is growing rapidly in Vilnius. Therefore, Vilnius is forced to adopt innovative solutions that promote sustainable mobility. This allows us to improve in the field of transport, to think about the future in the light of the directives provided by the EU and the growing environmental requirements. The city is investing heavily in renovating and improving the quality of its public transport park, expanding its network of cycle and pedestrian paths throughout the city, and talking more and more about the possible application of the metro. All of these tools promote the growing potential of multimodality, which together allow for a highly efficient and successful use of the "Park and Ride" platform. Proof of this form is noticeable positive examples in other European cities, such as Stockholm or Prague.

"Park and Ride" sites are part of the transport infrastructure and traffic planning system. It is one of the most popular tools for contributing to sustainable mobility and multimodality in cities. It is just one of many solutions needed to deploy for effectively taking advantage of the alternative traveling options created by the platform. Using this measure, paid parking lots are being built on the periphery of the city or at the entrances to the central part of the city, at points important for urban transport, where it is possible to travel comfortably by public transport after parking personal vehicle. In order to allow the "Park and Ride" project to operate efficiently, it is important that the network 
of such infrastructure is located throughout the city and its accesses. In of the Vilnius City Transport System the summer of 2017, Vilnius City Municipality opened three "Park and Ride" sites. Assessing the quality of the services provided by "Park and in the Context of Sustainable Ride" it is important to pay attention to the needs of current users and and Multimodality potential users of such services. The public opinion survey revealed that comfort, reduce journey time and costs are the most important criteria for road-users.

The evaluation of the Park and Ride sites was performed taking into account the results of the quantitative research method obtained by the survey from the public opinion poll and the collected statistical data. This method of research was chosen because quantitative research was characterised by the search for signs of an external phenomenon, obtaining various quantities that could be measured and calculated. Therefore, this research method is suitable for checking relationships and topics in the population. Quantitative research is important because the problem analysed in the article is closely related to society, its behaviour, opinion and attitudes towards transport. A total of 215 respondents, who got acquainted with the Vilnius city transport system, participated in the public opinion poll. The contingent of the respondents was selected in an effort to match the data provided by the Lithuanian Department of Statistics on the distribution of citizens living in the city by age groups, which allowed achieving more accurate results that would be closer to the actual opinion of the whole society. The received and analysed answers to the questionnaire survey allowed finding out the established travel habits of Vilnius city residents, the reasons for such habits and the attitude towards more environmentally-friendly alternative travel methods, especially distinguishing the services provided by the "Park and Ride" platform.

An analysis of secondary statistics was also performed. During it, publicly available data on the intersections of Vilnius, which generate the largest traffic flow, the number of inhabitants of different districts of the city and their distribution, as well as the number of individual users of the "Park and Ride" platform installed in Vilnius were analysed. Based on these data, a correlation analysis was performed, the distribution of data and other relationships between these indicators were observed. The observed interdependencies of the indicators allowed noticing the most important parameters of the travel choice and its quality assurance for the citizens, according to which the point evaluation of the "Park and Ride" sites was performed.

In order to better understand the "Park and Ride" platform advantages and disadvantages, an individual analysis of each currently operating site was performed, by assessing the most important aspects of the site: the attractiveness of the site to potential users, the location 


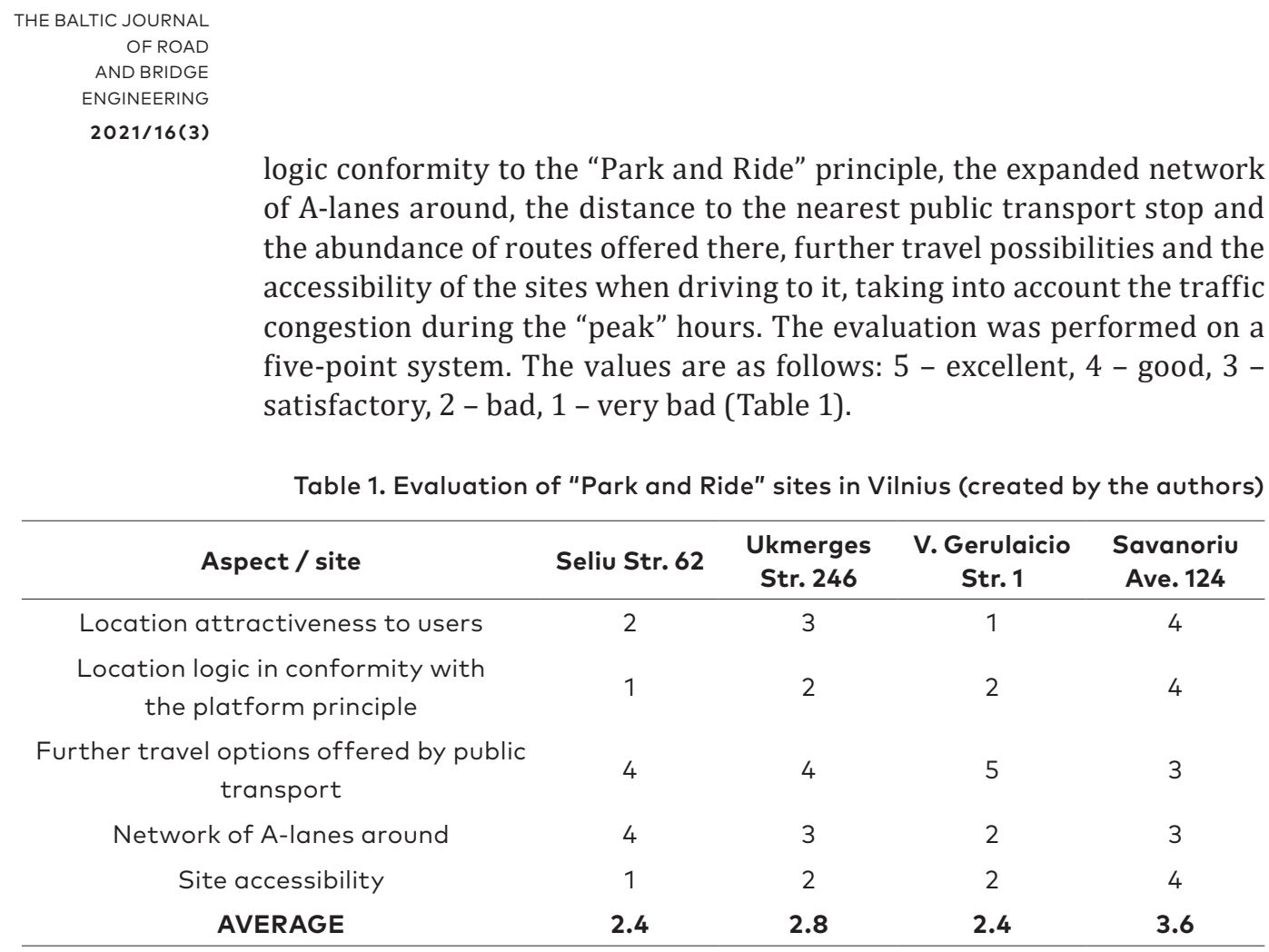

The results of the assessment of the "Park and Ride" platform sites show that even three sites are assessed more negatively than positively. These sites are mostly unpopular due to their badly chosen location and limited accessibility of the sites during the "peak" hours. The only one site on Savanoriu Avenue 124 has been built considering all the aspects that are most important to its users, as none of the evaluation indicators rated it worse than "satisfactory", which resulted in a high overall rating of the site.

The main reasons for the unpopularity of "Park and Ride" in Vilnius:

- the sites are located too close to the central urban area and are targeted at the wrong audience;

- during "peak" periods, the sites are mostly reached by crossing at least a few high-traffic intersections and getting into traffic jams;

- the use of the platform does not give the advantage of time and does not allow reaching the destination faster;

- strong attachment of citizens to personal vehicles and the facilities provided.

Identification of problematic areas. The performed general analysis of Vilnius city transport system has allowed noticing the most problematic areas of Vilnius city transport system: 
1. A strong public attachment to personal and, mostly, old vehicles, which has a consequent effect on higher traffic jams and environmental pollution.

2. Low speed of public transport due to the underdeveloped A-lane network and low interaction of public transport with other measures ensuring sustainable mobility and multimodality in the city.

3. Outdated and difficult-to-innovate habits of citizens, which hinder the faster implementation of sustainable mobility measures, as many of these innovations are not very popular and not supported by the society.

4. In a useless and impractical way, the city has started to develop the "Park and Ride" platform, which is one of the main tools ensuring sustainable mobility and multimodality in the city.

\section{Proposals for improving the efficiency of the Vilnius city transport system}

Despite significant investment and continuous improvement, the transport infrastructure and the entire urban road network are not able to manage the ever-increasing traffic flow during "peak" hours without traffic jams, resulting in economic, environmental and time losses. These losses are directly and indirectly felt by the majority - business, society, nature. As an alternative to deal with the situation and considering the long-term strategic EU plans and recommendations, in 2018 Vilnius city municipality prepared the SMP in Vilnius city. The main goals of the plan are to promote the use of public transport, to improve the efficiency of urban logistics and to increase the possibilities of non-motorized travel by forming habits of such traveling. One of the main measures to achieve such goals is the "Park and Ride" sites. The proper functioning of this measure in the city is particularly important, as it directly determines the transition from private vehicle to public transport, thus immediately creating a trip based on multimodality and sustainable mobility. Improving the efficiency of the urban transport system requires the expansion, renewal, and integration of the "Park and Ride" site network with other measures to ensure sustainable mobility in the city, all of which are more attractive to use.

Based on the analysis of the currently operating "Park and Ride" sites, solutions are presented (Table 2). 


\begin{tabular}{|c|c|}
\hline Site & Solution \\
\hline Seliu Str. 62 & $\begin{array}{l}\text { To open a new "Park and Ride" site in a more attractive location in Pilaite } \\
\text { district. } \\
\text { It is also proposed to renovate the old site on Seliu Street by adapting it to } \\
\text { the non-motorized users. It is planned to supplement the site with vacant / } \\
\text { occupied space calculation and lighting systems, information board. }\end{array}$ \\
\hline Ukmerges Str. 246 & $\begin{array}{l}\text { To leave the site in its current location because it is not very faulty, and its } \\
\text { relocation to a more purposeful location on Ukmerges Street requires large } \\
\text { investments and does not pay off. To install a vacancy / occupancy counting } \\
\text { system on the site and to expand the lighting system, to build an information } \\
\text { board. }\end{array}$ \\
\hline V. Gerulaičio Str. 1 & $\begin{array}{l}\text { To open a new "Park and Ride" site in the direction of Nemencine Rd. The } \\
\text { only site on the Nemencine Rd. already with partial infrastructure that is } \\
\text { easy to reach, paved, and has a nearby public transport station with a wide } \\
\text { selection of public transport meets most of the requirements for this type } \\
\text { of site. } \\
\text { To leave the existing site in operation in the current location on V. Gerulaicio } \\
\text { Str. by additionally installing vacancy / occupancy counting and lighting } \\
\text { systems, to build an information board. }\end{array}$ \\
\hline Savanoriu Ave. 124 & $\begin{array}{l}\text { The location of the site is appropriate; the site must be left in its current } \\
\text { location. To install additionally vacancy / occupancy counting and lighting } \\
\text { systems, to build an information board. }\end{array}$ \\
\hline
\end{tabular}

The new sites will be reached by avoiding intersections, which are usually characterised by high traffic. Using the services of new sites and public transport, these intersections will be overcome faster with the help of A-lanes, located on Pilaites Avenue and Ozo Street. Also, it will be easier to reach the locations of the new sites for the large number of rural residents living nearby, so benefits of the "Park and Ride" system are the most acceptable to these residents.

The "Park and Ride" site is planned at Vyduno Str. 20: dimensions of the site $-46 \mathrm{~m} \times 41 \mathrm{~m}$, pavement of the site - paved with pebbles, planned capacity - 77 cars. The "Park and Ride" site is planned at Nemencines Rd. 13: dimensions of the site $-32 \mathrm{~m} \times 24 \mathrm{~m}$, pavement of the site - asphalt, planned capacity -33 cars.

It is planned to connect the "Park and Ride" site at Seliu Street to the system of non-motor vehicles.

In addition, to ensure effective and positive "Park and Ride" impact, a very important question is capacity of public transport. Therefore, 
extensive measures are being taken to ensure the capacity and of the Vilnius City Transport System in the Context attractiveness of public transport. In recent years, the public transport bus park has been strongly renewed and its quality has been improved. Surveys and needs studies of citizens are also carried out on a regular of Sustainable basis to better select routes and their frequency for public transport. Other public transport infrastructure is being improved, which allows ensuring the priority and speed of public transport in the city. In addition, it helps for better distribution of passenger flows.

\subsection{Economic payback of the proposal}

The period is determined during which the initial investment in the project is recovered in order to calculate the payback of the proposal. In this case, it is necessary to anticipate potential future changes in the use of "Park and Ride" sites and to calculate the amount of revenue that the intended users will generate. It is also necessary to anticipate the costs of maintaining the sites and to increase these costs in line with the effects of inflation. All these calculations are based on the available data from the existing "Park and Ride" sites and on other foreseeable circumstances that may arise.

The results obtained in the economic payback calculations of project are presented graphically. The payback of the proposal in terms of cumulative value is shown in Fig. 2.

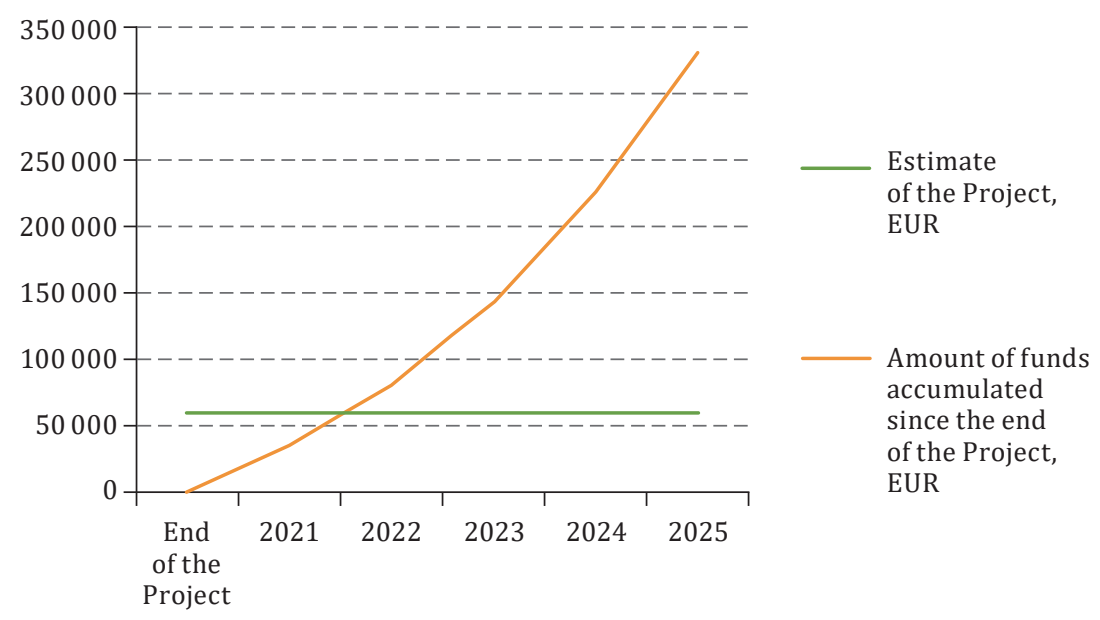

Figure 2. Project payback by accumulating earned income (created by the authors) 
The payback of the project in estimating operating costs is presented in Fig. 3.

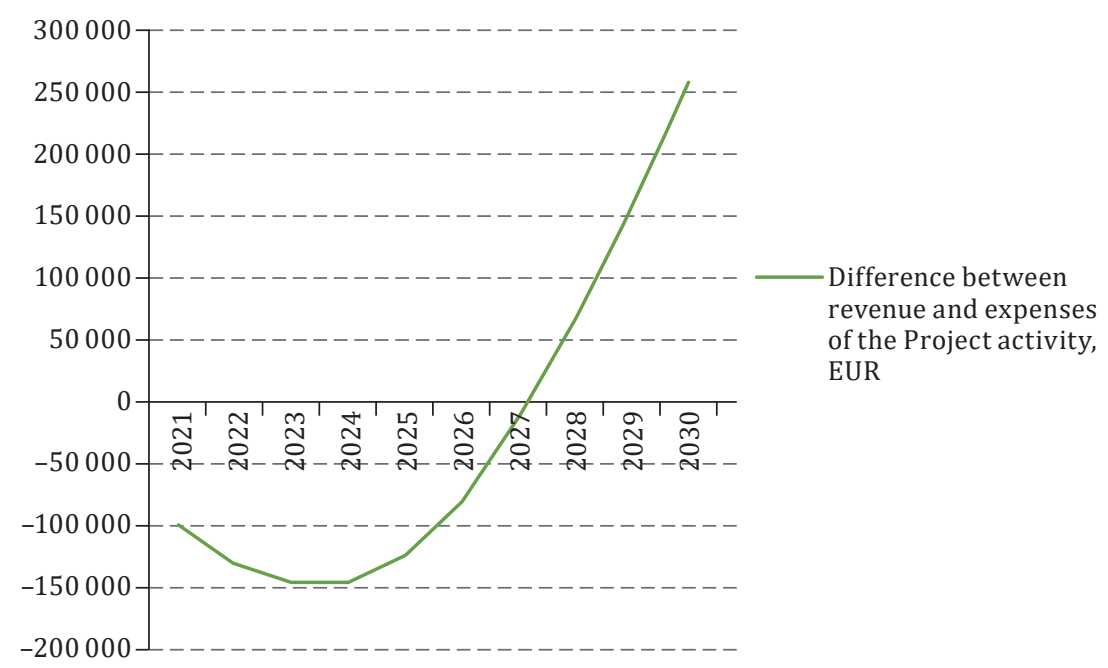

Figure 3. Payback of the project in estimating operating costs (created by the authors)

\subsection{Ecological payback}

Ecological payback calculations of the project were based on data from the Victoria Transport Policy Institute (VTPI) in Canada, which conducts independent research seeking to solve problems caused by transport. In March 2020, the VTPI published the results of a study and provided an estimated financial assessment of the environmental damage caused by vehicles, Victoria Transport Policy Institute (Canada) (n. d.). The calculations of the VTPI considered the social damage caused by transport, the environmental damage, the cost of reducing emissions, and the prices of world oil and coal markets. The Institute provided the values of damage caused by light vehicles, after converting them into more acceptable units of measurement in Lithuania, the calculations of ecological savings were performed (see Table 3 ). 


\begin{tabular}{cc}
\hline Damage & $\begin{array}{c}\text { Value } \\
\text { in EUR/100 km }\end{array}$ \\
\hline Damage causing greenhouse effect & 8.34 \\
Other air pollution damage causing non-greenhouse effect & 2.265 \\
Damage of greenhouse effect control measures & 0.959 \\
\hline
\end{tabular}

Based on a monetary assessment of the damage caused by light vehicles provided by the Institute for Transportation \& Development Policy in the USA, an ecological savings calculation was performed and presented graphically (Fig. 4).

Calculations show that in total, thanks to the "Park and Ride" platform users, 4050740 kilograms of $\mathrm{CO}_{2}$ emissions will be avoided during the forecast decade in the territory of Vilnius city, where the accumulated value of ecological savings will reach about EUR 2055818. Emissions, which will not be emitted by other traffic participants not using "Park and Ride", but spending less time in traffic due to the users of the platform, can also be added to this amount.

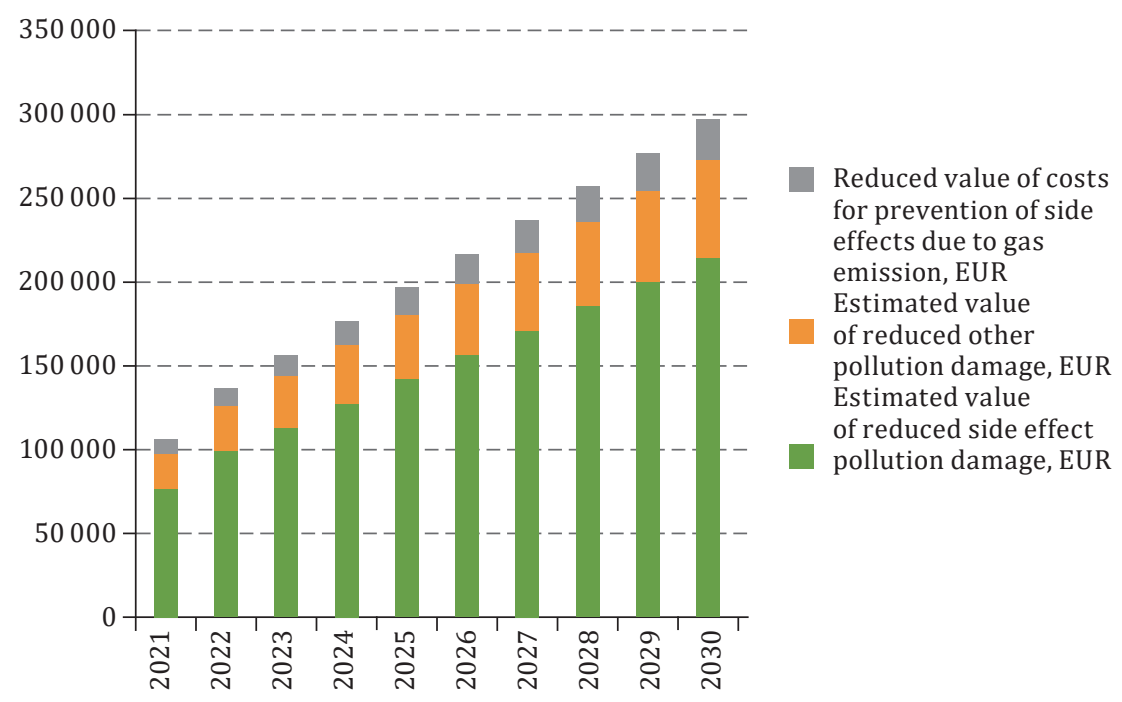

Figure 4. Planned value of ecological savings in monetary terms (created by the authors) 
THE BALTIC JOURNAL

OF ROAD

AND BRIDGE

ENGINEERING

$2021 / 16(3)$

The new "Park and Ride" sites installed on strategically located places with a network of A-lanes in public transport routes will allow their users to avoid traffic jams during "peak" periods and to reduce about $40-70 \%$ of the total journey time, considering that usually the journey takes longer due to traffic jams. Estimating the typically 30\% slower movement of public transport compared to a private car, the final savings for "Park and Ride" users are about 10-40\% of the total journey time. Such an indicator would save about 10 minutes per day, which, taking into account the planned number of "Park and Ride" users for the next decade and the average value added per hour generated by Vilnius residents, would create a total value added of EUR 3894700 during the entire period.

It is planned that 1168410 users will use the "Park and Ride" services in the next decade. One user of the platform makes at least two trips (from the site and back) without personal transport, and, on the way to an additional destination, often even more. In total, there will be about 4 million fewer trips made by personal light cars in a decade. Assessing the usual number of trips per day in Vilnius city, these savings are less than half a percent, but considering that most of these trips take place at the same time and are mostly in the same central part of the city, this may allow creating 1-2\% lower traffic flows in those zones.

The planned use of the renewed "Park and Ride" platform will result in an average of almost 2 million fewer kilometres per year by personal car, about half of which would be in the city centre, so this distance saving will reduce the noise and other pollution levels normally caused by transport in the most affected parts of the city - Centre, Seskine, Snipiskes.

All planned benefits provided by the platform have been calculated based on results of the planned development and renewal of the "Park and Ride" platform and other current features of the Vilnius city transport system infrastructure. However, considering the Vilnius city SMP and the goals set in it for the transformation of the city transport system, it can be assumed that the planned results obtained after the implementation of the project will be even better. The "Park and Ride" platform is just one of many solutions ensuring sustainable mobility, multimodality, modernity, convenience and ecological benefits when traveling in the city. After implementation of other solutions promoting sustainable mobility and after integration of the network of all of them into a common system, these solutions will have a significantly greater long-term positive effect than those taken separately. 


\section{Conclusions and recommendations}

1. The article show that scientific literature has largely contributed to defining long-term strategic measures to improve the efficiency of the transport system, with a focus on sustainable urban mobility and multimodality.

2. Among many possible solutions, the scientific literature recommends improving road traffic infrastructure and traffic planning and management processes, developing infrastructure and introducing alternative working hours.

3. It has been clarified that Vilnius city has a well-developed road transport network and other necessary financial and technological resources that can help solve the problems of the transport system arising from the high attachment of citizens to personal vehicles and from the inefficient use of facilities ensuring the sustainable mobility.

4. Performed calculations show that the implementation of the "Park and Ride" platform will provide various benefits in the long run. It is proposed to implement this project in Vilnius City Municipality, as the solutions will allow for an increase in the number users, and ensure the economic profitability of the project.

5. Estimates suggest that the renewed and expanded network of "Park and Ride" sites will also bring ecological and social benefits, as the use of the platform will significantly contribute to the reduction of environmental and noise pollution, congestion, traffic, waste of time and road fatalities in the future.

6. It is recommended that the institutions responsible for the efficiency of the Vilnius city transport system continue to carry out the tasks provided for in the sustainable urban mobility plan, as their implementation will ensure long-term and reversible benefits in the future. It is also recommended to continue investing in various projects promoting sustainable mobility, networking them and creating greater benefits for society and the city. It is advisable to consider the international good practice and to adapt the solutions to the areas of Vilnius city transport system needed for improvement. of the Vilnius City

Transport System

in the Context

of Sustainable

Mobility

and Multimodality 
THE BALTIC JOURNAL OF ROAD AND BRIDGE ENGINEERING $2021 / 16(3)$

\section{REFERENCES}

Baublys, A., \& Vasilis Vasiliauskas, A. (2011). Transporto infrastruktūra. Technika. https://doi.org/10.3846/1203-S

ITS Vilniaus transporto sistemoje. (n. d.). Judu. http://www.vilniustransport.lt/lt/news/view/?id=1185\&fbclid=IwAR3xN1o tXu_duY3Wa-QyMYHfY0aF1fR5j662Cb94SLid-bNY-PSny4vJC3Q

Jarašūnienè, A. (2008). Intelektinés transporto sistemos. Technika. https://doi.org/10.3846/1424-M

Jaržemskis, A., \& Jaržemskis, V. (2017). Keleivinis transportas. Technika. https://doi.org/10.20334/2017-022-S

Jaržemskis, V., Jakubauskas, G., \& Mačiulis, A. (2012). Transporto politikos pagrindai. Technika. https://doi.org/10.3846/1279-S

Kardelis, K. (2016). Moksliniu tyrimu metodologija ir metodai. Vilnius: Mokslo ir enciklopedijų leidybos centras.

Minalga, R. (2009). Logistika versle. Vilnius.

Pėsčiųjų takų plètra. (n. d.). Verslo Žinios. https://www.vz.lt/laisvalaikis/ pomegiai/2019/05/16/vilniuje-tiesiamas-naujas-dviraciu-ir-pesciuju-takas

Rodrigue, J. P., Comtois, C., \& Slack, B. (2006). The geography of transport systems. U.S.A.

Rokicki, B., \& Stepniak, M. (2018). Major transport infrastructure investment and regional economic development - An accessibility-based approach. Journal of Transport Geography, 72, 36-49. https://doi.org/10.1016/j.jtrangeo.2018.08.010

Šiauriné gatvè. (n. d.). www.15min.lt. https://www.15min.lt/gazas/naujiena/ gatve/taip-atrodys-nauja-gatve-vilniuje-6-eismo-juostos-su-saligatviais-irdviraciu-takais-221-942814

Sodiq, A., Baloch, A. A. B., Khan, S. A., Sezer, N., Mahmoud, S., Jama, M., \& Abdelaal, A. (2019). Towards modern sustainable cities: Review of sustainability principles and trends. Journal of Cleaner Production, 227, 972-1001. https://doi.org/10.1016/j.jclepro.2019.04.106

Statyk ir važiuok. (n. d.). Vilniaus m. savivaldybè. https://vilnius.lt/lt/tag/statyk-ir-vaziuok/

Tidikis, R. (2003). Socialiniu mokslu tyrimu metodologija. Lietuvos teisès universiteto Leidybos centras.

Vasilis Vasiliauskas, A. (2013). Krovinių vežimo technologijos. Klaipėda.

Victoria Transport Policy Institute (Canada). (n. d.). Transport damage assessment, VTPI. https://www.vtpi.org/tca/tca0510.pdf?fbclid=IwAR0wUv SJNS0BVf93uY82IjaFMVAdTibs75wsak2cZ_V9HgvnoejkqCf46uc

Vilniaus miesto darnaus judumo plano santrauka. (n. d.). Vilnius. https://drive. google.com/file/d/1DpFYlC5Lb8WbKJwJTKc3-GVNb_FN0P86/view

Zhuang, Y., Zhou, X.d., Ni, Y., \& Yang, L. (2017). Passengers behavioral intentions towards congestion: Observational study of the entry restrictions at traffic bottleneck. KSCE J Civ Eng 21, 2393-2402.

https://doi.org/10.1007/s12205-016-1688-6 